UNDERGRADUATE RESEARCH IN NATURAL AND CLINICAL SCIENCE AND TECHNOLOGY (URNCST) JOURNAL Read more URNCST Journal articles and submit your own today at: https://www.urncst.com

\title{
The 1st Annual McMaster Energy Week: Smart Energy City Competition
}

Damien Joseph, BSc Student [1]*, Hanu Chaudhari, BHSc Student [1], Ryan Rogers, BEngMgmt [1,2]

[1] McMaster University, Hamilton, ON, Canada

[2] McMaster Institute for Energy Studies

*Corresponding Author: josepd4@mcmaster.ca

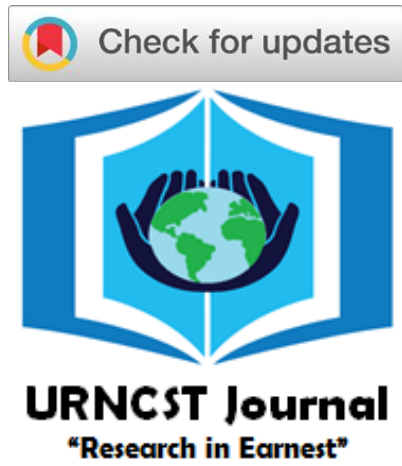

\begin{abstract}
The following abstracts were selected as the top 3 finalists amongst the delegates chosen for the Smart Energy City Competition taking place during the 1st annual McMaster Energy Week. McMaster Energy Week is Canada's first studentled energy week that aims to take the complex and multi-faceted issue of climate change and present solutions towards building Canada's sustainable future. We are bringing together academia, industry, government, communities, and students to further the dialogue on Canadian environment and energy. For more information on this visit https://www.mcmasterenergyweek.com/ or email chair@ mcmasterenergyweek.com.
\end{abstract}

Keywords: McMaster Energy Week; undergraduate research competition; carbon neutrality; sustainability; interdisciplinary research; climate change; research; innovation

Table of Contents

Abstracts of Oral Presentations

pg. A01-A03

\section{Conference Abstracts}

Note: These abstracts have been reproduced directly from the material supplied by the authors, without editorial alteration by the staff of the URNCST Journal. Insufficiencies of preparation, grammar, spelling, style, syntax, and usage are the authors.

\section{Abstracts of Oral Presentations}

Smart energy city solutions: Closing the waste-agriculture loop

Graeme A. Crawley, BEng Candidate [1], Melissa Cusack Striepe, BEng Candidate [2], Daniel LaFrance, BEng Candidate [3], Hannah McPhee, BEng Candidate [4], Vincent Popovich, BEng Candidate [5],

[1] Department of Computing and Software, McMaster University, Hamilton, Ontario, Canada L8S 4L8

[2] Department of Chemical Engineering, McMaster University, Hamilton, Ontario, Canada L8S 4L8

[3] Department of Civil Engineering, McMaster University, Hamilton, Ontario, Canada L8S 4L8

[4] Department of Engineering Physics, McMaster University, Hamilton, Ontario, Canada L8S 4L8

[5] Department of Materials Science and Engineering, McMaster University, Hamilton, Ontario, Canada L8S 4L8

Every year in Ontario, approximately 1,000,000 tonnes of food waste are produced and not utilized. Our proposed solution aims to close the loop between food production and food waste, in order to mitigate the GHG emissions of both areas. The solution deals with food waste in three tiers: community food, forage, and waste to energy. The community food tier deals with distributing edible food waste from retailers to food banks and community kitchens, to mitigate community food insecurity. These needs can be met with only $0.2 \%$ of the community's food waste. The second tier tackles forage, food produced for livestock feed. By utilizing a 200000 person community's edible food waste, 1930 hectares of land can be converted from forage production to carbon sequestering forests or wetlands. This translates to 3.5 million $\mathrm{kg}$ of $\mathrm{CO} 2$ sequestered each year. Finally, with the "bad" compost not suitable for consumption, our system turns waste into energy through an anaerobic digester coupled with a combined heat and power plant. Energy produced from the food waste is able to power greenhouses and other agricultural activities, reducing the greenhouse emissions by 256 tonnes of $\mathrm{CO} 2$ emissions per 
UNDERGRADUATE RESEARCH IN NATURAL AND CLINICAL SCIENCE AND TECHNOLOGY (URNCST) JOURNAL Read more URNCST Journal articles and submit your own today at: https://www.urncst.com

year. Excess bio-gas and electricity is sold back to the community, while excess heat is stored using geothermal storage on site.

Entomophagy as a solution to agricultural greenhouse gas emissions: A research study

B. Haque, BSc Student [1], P. Wang, BSc Student [1], C. Au-Yeung, BSc Student [1], M. Ahmed, BSc Student [1], M. Fogal, BSc Student [1]

[1] Department of Science, McMaster University, Hamilton, Ontario, Canada L8S 4L8

The rapid growth of the meat industry, namely beef, pork, and poultry, has caused huge impacts on the environment due to its high carbon emissions spanning across several sectors. In addition, food security poses a major concern due to the rising global population. As a result, the world must transition to a new source of protein; the agricultural growth of crickets, also known as entomophagy, has extremely high potential to prevent world hunger and reduce carbon dioxide emissions. Crickets have more than two times the protein of conventional meat per mass and can be produced and sold at a much lower price than conventional meat. The implementation of cricket farms in a local community will decrease the city's carbon emissions of the agricultural sector by $64.3 \%$ if crickets replace $80 \%$ of the current meat diet, and $80.4 \%$ if they completely replace conventional meat. This will be accomplished over a 30-year period and overseen by municipal government. Cricket farming will also decrease the carbon dioxide emissions from waste and transportation sectors since crickets feed off of organic waste and are farmed locally. The crickets will breed during a six-week harvest cycle in correspondence to their life cycle and will increase job availability within the community. The paradigm shift to acceptance of entomophagy includes a series of education and awareness policies. While being clean and reliable, entomophagy is the innovative solution to the reduction of global carbon dioxide emissions.

Commercial energy \& efficiency to 2050+

Nikhil Gupta, B.Eng.Mgt Student [1], Kevin Perera, B.Eng.Scty Student [1], Matthew Poloni, B.Eng Student [2], Timothy Yeung, B.Eng.Mgt [1]

[1] Department of Mechanical Engineering,Mcmaster University, Hamilton, Ontario, Canada

[2]Department of Engineering Physics Hamilton, Ontario, Canada

Commercial properties use an estimated $87 \%$ of their energy for what is termed "comfort processes". These processes include heating, lighting, and other HVAC functions such as air conditioning. Building system and structural efficiencies can greatly reduce the amount of energy required for these processes. Given that the majority of heating in a commercial building, which possesses a very large volume to footprint ratio, is accomplished with natural gas, heating processes contribute significantly to carbon emissions. Reducing the need for natural gas heating can be accomplished first through the use of higher R-value building materials, specifically insulation and windows. Current and old construction standard utilize fiberglass batts and dual pane windows, which only offer modest heat retention. Replacing these structural components with insulation such as rigid polyurethane foam and three panel windows incorporating argon gas filling and coatings to reduce the penetration of solar irradiance. Using parallel thermal resistance calculations performed on a per unit external surface area, it is estimated that for high glass to surface area ratio buildings energy loss can be reduced up to $44 \%$. These improvements alone can yield a maximum savings on carbon emissions of approximately $26.7 \%$ for commercial carbon emissions. To complement the above solution, moving building heating sources away from pure natural gas fired appliances to alternative, newer technologies can yield additional savings. Heat pumps are considered an alternative, with ground source heat pumps (GSHPs) offering low-carbon alternative setups. Incorporating a GSHP into building design yields additional carbon savings, however the magnitude of these savings is highly dependent on building setup and the dependence of grid electricity. Using adapted models, this technology combined with the aforementioned building envelope changes yields carbon emissions reductions of $49.8 \%$. In order to implement these changes, modifications to municipal and/or provincial building codes to increase the standards to meet the aforementioned reductions is advised. These changes performed on a municipal level can be targeted to achieve new build compliance in the near-future, with complete retrofitting of old structures by 2050 for greatest reductions. It has been determined that the demolition and replacement of old structures for the purposes of carbon emissions reduction introduces a considerable "carbon payback" period due to emissions from the demolition and construction processes that are not incurred during retrofitting. This is evidenced by the complete retrofit of the UN complex in New York, a case study referenced in the main report. In order to incentivise building and property owners to make these retrofit changes without legislative mandate, tax rate reductions can be used through the creation of a new tax category for these green commercial buildings. Current municipal property tax rates are approximately $1.8 \%$, with reductions to $1.6 \%$ yielding respectable annual savings to those constructing new commercial buildings with only moderate impact on municipal tax revenue. Quantification

Joseph et al. | URNCST Journal (2018): Volume 2, Issue 3

DOI Link: https://doi.org/10.26685/urncst.46

Page A2 of A4 
UNDERGRADUATE RESEARCH IN NATURAL AND CLINICAL SCIENCE AND TECHNOLOGY (URNCST) JOURNAL
Read more URNCST Journal articles and submit your own today at: $\underline{\text { ttps://www.urncst.com }}$

of the impact on tax revenue for retrofits is not performed, as highly variable circumstances have yet to be accounted for to estimate the number of successful retrofits. Impacts on municipal tax revenue can be offset through federal funding from the Canadian Infrastructure Bank and provincial green initiative funds from cap and trade proceeds. Any incentives or further tax cuts to limit the impact on small businesses from mandatory building code revision can be outlined in a comprehensive Community Improvement Plan legislated into action by the municipality. Benefits of such widespread specialist construction and retrofitting processes can improve the local community through increasing the number of jobs in both construction and materials supply sector, increasing heat pump production to achieve serial production benefits, as well as increasing the competitiveness of existing development entities by gaining specialist construction knowledge and experience.

\section{Conflicts of Interest}

The authors declare that they have no conflict of interests.

\section{Authors' Contributions}

HC: Founder and Chair of the $1^{\text {st }}$ annual McMaster Energy Week.

RR: Served as Case Competition Lead, developing the case and aiding delegates in the development of their case proposals and abstracts.

DJ: Served as Competition Logistics and Delegate Coordinator, drafted the competition book and reviewed abstract submissions.

\section{Acknowledgements}

Special thanks to our graduate student mentors, whose guidance and wisdom was integral in the success of the development of the case proposals and the competition as a whole. We would like to also thank the judging panel for their time and critical appraisal on the day of the competition.

\section{Funding}

We would like to thank our generous sponsors for their financial support for McMaster Energy Week: Alectra, HCE Energy Inc., Ontario Power Generation, SNC Lavalin, McMaster Engineering Society, McMaster Faculty of Engineering, McMaster Office of the President, S2E Technologies, and Canada's Energy Citizens.

\section{Article Information}

Managing Editor: Jeremy Y. Ng

Article Dates: Received Mar 14 18; Published Mar 1618

\section{Citation}

Please cite this article as follows:

Joseph D, Chaudhari, H, Rogers, R. The 1st annual McMaster energy week: Smart energy city competition. URNCST Journal. 2018 Mar 16: 2(3). https://urncst.com/index.php/urncst/article/view/46

DOI Link: https://doi.org/10.26685/urncst.46

\section{Copyright}

(C) Damien Joseph, Hanu Chaudhari, Ryan Rogers. (2018). Published first in the Undergraduate Research in Natural and Clinical Science and Technology (URNCST) Journal. This is an open access article distributed under the terms of the Creative Commons Attribution License (https://creativecommons.org/licenses/by/4.0/), which permits unrestricted use, distribution, and reproduction in any medium, provided the original work, first published in the Undergraduate Research in Natural and Clinical Science and Technology (URNCST) Journal, is properly cited. The complete bibliographic information, a link to the original publication on http://www.urncst.com, as well as this copyright and license information must be included. 


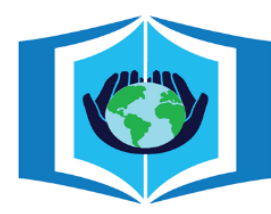

URNCST Journal

"Research in Earnest"

\section{Funded by the Government of Canada}

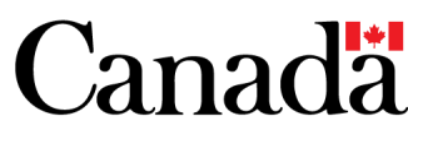

Do you research in earnest? Submit your next undergraduate research article to the URNCST Journal!

| Open Access | Peer-Reviewed | Rapid Turnaround Time | International | | Broad and Multidisciplinary | Indexed | Innovative | Social Media Promoted |

Pre-submission inquiries? Send us an email at info@urncst.com | Facebook, Twitter and LinkedIn: @URNCST Submit YOUR manuscript today at https://www.urncst.com! 